\title{
ИСТОРИЯ РАЗВИТИЯ И ЗНАЧЕНИЕ ПЕРВЫХ КРУПНЫХ ОСОБО ОХРАНЯЕМЫХ ПРИРОДНЫХ ТЕРРИТОРИЙ ГЕРМАНИИ В XIX-НАЧАЛЕ XX ВЕКА
}

\section{А.С. Мукало \\ Саратовский государственный университет, кафедра физической географии и ландшафтной экологии E-mail: anastasia-mukalo@yandex.ru}

В XIX в. под влиянием романтизма, потребности в национальном определении и исходя из общественно-экономической ситуации в объединяющейся Германии были созданы первые относительно крупные по площади особо охраняемые природные территории (ООПТ), причем еще до создания национальных парков в США и до оформления национальной программы охраны природы. В статье рассматривается несколько охраняемых территорий того времени, которые по своим задачам и организации максимально напоминают современные. Примечательна для Германии история их развития как ООПТ - благодаря частной, общественной и государственной инициативам.

Ключевые слова: Германия, XIX в., охрана природы, особо охраняемые природные территории, природные парки, Бамбергская роща, Драхенфельс (Семигорье), Тойфельсмауэр (Гарц), Люнебургская пустошь, общественные природоххранные союзы.

The Development History of and Value of the First Large Protected Areas in Germany in the 19th - the Beginning 20th Centuries

\section{A.S. Mukalo}

The first, rather large protected areas in Germany were created in 19th century under the influence of romanticism, requirements to national definition and proceeding from a socioeconomic situation. It occurred before national parks in USA were created and the German nature protection program formed. The article presents those of them which as much as possible resemble modern nature parks in their problems and organization. The history of their development as protected areas is characteristic for Germany thanks to private, public and state initiatives.

Key words: Germany, 19th century, nature conservation, nature protection, protected areas, nature parks, Bamberg grove, Drachenfels (Siebengebirge), Devils Wall (Harz), Lüneburg heath, the nature protection unions.

\section{Введение}

В Германии исторически сложилось несколько категорий особо охраняемых природных территорий (ООПТ) - наряду с ландшафтными заповедниками и памятниками природы, изначально получившими свое развитие в этой стране, в середине XIX в. проявилась тенденция к созданию крупных по площади охраняемых территорий. В XX в. эти идеи были претворены в жизнь, благодаря чему появились новые категории ООПТ по

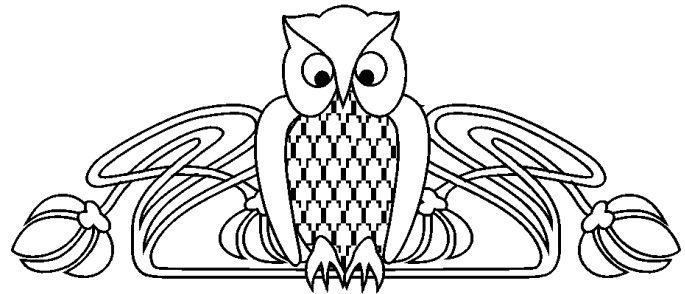

образцу иностранных (национальные и природные парки). После объединения ФРГ и ГДР стали формироваться ООПТ, входящие в общеевропейскую и международную системы (биосферные резерваты, участки, охраняемые по Рамсарской конвенции, Natura 2000 и т.п.). В настоящее время в Германии сеть ООПТ представляют 14 национальных парков, 14 биосферных заповедников, 94 природных парка, несколько десятков тысяч памятников природы и ООПТ регионального значения. Целью данной статьи является подробное изучение развития первых природных парков в Германии и их роли в дальнейшей истории природоохранной деятельности.

Ценность природного ландшафта в Европе осознали приблизительно спустя тысячу лет после его исчезновения [1]. Поэтому, несмотря на громкие заявления разнообразных общественных объединений и государственных ведомств, охрана природных ландшафтов в Германии свелась к охране культурного ландшафта, т.е. территорий, которые претерпели разной степени антропогенные изменения в давнем или недавнем прошлом. Этот аспект, как правило, всегда надо иметь в виду, когда речь идет о каких-либо ООПТ в Европе. Неудивительно, что большая часть крупных ООПТ Германии имеет комплексный характер: наряду с природными особенностями внимание ученых и туристов привлекают исторические памятники.

Впрочем, разрозненные свидетельства об охране природы на территории современной Германии восходят к давним временам. Датой первого охранного постановления относительно природного объекта в Германии называют и XVIII в. (1739 г. - распоряжение об охране дюн на о. Сыльт) [2], и XVII в. (сталактитовая пещера под Рюбеландом, указ Рудольфа Августа, герцога брауншвайгского и люнебургского в 1668 г.) [2, 3], и XIII в. (самое старое положение об охране лесов было издано в 1274 г. герцогом Альбрехтом Брауншвайгским) [4].

Согласно общепринятым в академической среде спискам основных хронологических событий в области охраны природы в Германии $[2,5,6]$ к одним из достаточно крупных охраняемых территорий в этой стране, появившихся в XIX в. и понимаемых как ООПТ в современном смысле, относятся Бамбергская роща, гора Драхенфельс под Бонном, останцы Тойфельсмауэр в Гарце. Считалось, что они по мере возможности служат целям естественно-научных изысканий, просвещению и воспитанию народного духа, поэтому 
при некотором уровне «закрытости» и очевидном ограничении в хозяйственном использовании в них допускались (и даже приветствовались) посещения отдыхающих и любопытствующих.

Если рассматривать и те территории, которые в то время относились к Германскому Союзу (1815-1866 гг.) и Германской империи (1871-1918 гг.), то стоит упомянуть богемские леса графов Букой в Гратцене (1838 г.) и леса князя Шварценберг близ Кубаны (1858 г.) [7]. Леса Келлервальд в Гессене и меловой уступ Кёнигсштуль на острове Рюген как ООПТ в XIX-начале XX в. менее похожи на природные или национальные парки в современном представлении. Область Келлервальд была охотничьей территорией князей фон Вальдек, которые в 1897 г. соорудили решетчатую ограду вокруг некоторых участков леса главным образом для того, чтобы защитить популяции диких животных [8]. В 1935 г. площадь в пределах решетки расширилась. В 1952-1990 гг. это был заповедник. После многолетних требований природоохранных групп в 2004 г. был основан национальный парк Келлервальд-Эдерзее, задачей которого является сохранение букового леса [9]. Меловые скалы, эрратические валуны на побережье и леса на острове Рюген, в свою очередь, были очень популярны среди путешественников и любителей красот природы в ХІХ в. Однако никаких охранных мероприятий относительно них не проводилось. Естественные обнажения мела издавна разрабатывались. И только когда в 1926 г. одному из меловых карьеров, где разработки были прекращены, угрожало их возобновление, побережье к северу от Засница было поставлено под охрану и объявлено заповедником, а с 1990 г. этот участок стал национальным парком [10].

Долгая история создания природных парков Семигорье и Люнебургская пустошь очень показательна: были задействованы широкие народные массы, частная инициатива, общественные организации, отдельные важные государственные лица. Впервые в таких масштабах применялись механизмы отчуждения земель (экспроприация и выкуп участков), которые позднее найдут более широкое применение. Правда, до сих пор нет однозначной оценки их эффективности, и в законах приходится прописывать оба варианта: государственную и частную собственность. Для сравнения, признание заповедника Плагефенн, находящегося на территории современного биосферного заповедника Шорфхайде-Хорин, заняло всего три года (1904-1907 гг.). По сути, после выхода программной работы Гюго Конвентца в 1904 г. и создания Прусской государственной комиссии по охране памятников природы, оформление объекта как ООПТ свелось к подаче заявки в министерство по рекомендованной форме [11].

Формирование относительно крупных по площади ООПТ в Германии фактически началось задолго до создания первого национального парка (1872 г.) и охраняемой территории (1864 г.) в
США, по сути, еще до создания более-менее адекватной программатики движения (т.е. теории): до выхода в печать первых работ по охране природы «Об отношении современного общества к природе» (1880 г.) и «Охрана природного и культурного наследия родины» (1897 г.) Эрнста Рудорффа или такой базовой книги как «Угроза памятникам природы и предложения по их сохранению» (1904 г.) Гюго Конвентца [12]. Парадоксально то, что именно на США ссылались в конце XIX-начале XX в. все активные общественные деятели в области охраны природы. Разумеется, примером служили, прежде всего, системный подход к организации и масштаб деятельности: работа идет на государственном уровне, площади парков огромны для Европы XIX в. («Самый большой, Йеллоустонский национальный парк, имеет площадь 8671 кв. км, т.е. больше, чем великие герцогства Гессен или Ольденбург» [12, с. 185]).

Тем самым, конкретная история развития Бамбергской рощи, Драхенфельса в Семигорье, Тойфельсмауэра и Люнебургской пустоши как охраняемых территорий в XIX-начале XX в. представляет определенный интерес. В любом случае, история этих объектов как ООПТ все-таки старше, чем прописанные в законах понятия «национальный парк» или «охраняемый ландшафт». Этот феномен связан со сложившейся в первой половине XIX в. в Европе общественно-культурной обстановкой, в частности с идейным и культурноисторическим течением романтизм.

\section{Романтизм}

Романтизм утверждает культ природы, чувств и естественного в человеке в противовес эпохе Просвещения с культом разума $[13,14]$. Так что неудивительно, что в Германии среди отцов-основателей природоохранных движений так много людей творческих: поэтов, писателей, музыкантов, причем известных, достигших признания. В период расцвета литературы, музыки и живописи в XIX в. именно они оказались носителями идей романтизма и движущей силой по претворению их в жизнь. Романтизм, историзм и, прежде всего, натурфилософия создали эстетическую необходимость в природе, интерес к ней и желание ее сохранить в неизменном виде.

И в США, и в Германии дополнительным стимулом к созданию ООПТ стала потребность в национальном самоопределении, что неудивительно, если вспомнить историю этих стран [15]. В период формирования единой Германии с соответствующим культурным и промышленноэкономическим подъемом сама мысль о том, что природа - неотъемлемая часть страны, родины и поэтому подлежит охране, была новаторской [16]. В 1854 г. культуролог и один из самых консервативных публицистов своего времени Вильгельм Хайнрих Риль (1823-1897) обозначил как социально-политическую задачу охрану лесов: «В 
наших лесных деревнях еще сохранился уклад той естественной жизни в гармонии с природой. И не только лес, но и песчаные дюны, болота, пустоши, скалы, ледники - все это необходимое дополнение к полям. Остается только радоваться, что подобная красота сохранилась в нашей стране, она может служить источником народной силы и сознания. Лес необходим не только для отопления наших печей зимой, но и для биения пульса народа, чтоб Германия оставалась самой собой» [17, с. 359].

Позднее от восхищения могучей всесильной природой в эпоху романтизма человек переходит к осознанию ее беззащитности и хрупкости перед лицом разрушительного прогресса. Интенсивное развитие сельского хозяйства, мелиорация, сооружение плотин и регулирование течения рек, осушение болот, рационализация лесного хозяйства, строительство новых транспортных путей и рост урбанизации в эпоху Бисмарка преобразили разнообразные культурные ландшафты в однородное пространство, служащее людям. Следствием этого стали экологическое и эстетическое обеднение и деградация окружающей среды. Гуманистические идеалы вступили в конфликт с прозаической повседневностью и духовным кризисом буржуазного общества, нацеленного в первую очередь на материальные блага, а не на духовный рост. Херманн Лёнс (1866-1914), один из основателей природоохранного движения в Нижней Саксонии, критиковал скучный безрадостный ландшафт страны, оказывающий, по его мнению, деградирующее воздействие на нацию: «Движение по охране природы должно стать силой, такой силой, которая должна заставить считаться с собой промышленность, торговлю, транспорт, сельское и лесное хозяйство. Не надо бояться упреков, что мы мечтатели, реакционеры, враги прогресса или люди без практического взгляда на жизнь.<...> Охрана природы преподносится как чисто естественнонаучное движение, но это не так, напротив - это и борьба за здоровое сохранение немецкой нации, за силу и процветание. Убивать природу это все равно что самоубийство» [18, с. 13].

Интерес в эпоху романтизма к фольклору, истории и этнографии, а также мысли о том, что одна из целей охраны природы - формирование некоего «стержня» государства и сохранение нации, постепенно привели к тому, что в обществе активно заговорили об улучшении и очищении нации, о ее оздоровлении. Общеизвестно, к чему они привели в Германии.

Рассмотрим историю создания первых охраняемых территорий Германии.

\section{Бамбергская роща}

Бамбергская роща, пойменный лес в долине Майна, закреплена в правах ООПТ указом курфюрста баварского и пфальцского Макса IV в 1803 г. [19]. Территория заливных лугов с XIV в. использовалась как сельскохозяйственные угодья.
До передачи территории под застройку это место имело прозвище «У семи рек», так как здесь протекало много небольших боковых рукавов Регница, на которых работали многочисленные мельницы. Роща расположена, как и старая часть города Бамберг, на острове, который ограничивается на востоке правым, а на западе левым рукавом Регница, и состоит из двух участков [20]. Ее северную часть в 1803 г. Штефан Фрайхерр фон Штенгель по указу курфюрста превратил в так называемый народный парк (по культурно-исторической классификации) по примеру Английского парка в Мюнхене - с павильонами, памятниками, аллеями лип и тополей. Более крупную южную часть в 1825-1851 гг. постепенно выкупил город и преобразовал в ландшафтный парк, затем сюда перенесли ботанический сад. С 1870 г. вся роща находится во владении г. Бамберг. Сейчас это излюбленное место прогулок горожан. С 1975 г. роща находится в списке памятников г. Бамберг как старейший в Баварии городской парк, а с 2001 г. имеет статус охраняемого ландшафта европейского значения, отличающегося богатым разнообразием жуков и насекомых [21].

\section{Гора Драхенфельс}

Гора Драхенфельс (321 м) - самая невысокая в Семигорье, маленьком природном парке (охраняются в первую очередь леса) (рис. 1), расположенном на правом берегу Рейна южнее Бонна, споры о преобразовании которого в национальный парк не утихают. По легенде о Нибелунгах под уступом горы Зигфрид убил дракона (отсюда и название - буквально «Драконья скала»). В настоящее время на горе Драхенфельс, помимо разрушенной крепости - популярной достопримечательности, находится Музей истории природоохранной деятельности в Германии.

Уже римляне добывали трахит под вершиной Драхенфельса в разломе, узнаваемом и сегодня. В 1248 г., когда началось строительство Кёльнского собора, там была открыта каменоломня. В 1634 г. крепость на горе была разрушена в ходе военных действий, а ее остатки местные жители постепенно разбирали на стройматериалы, пока не возникла опасность того, что руины крепости обрушатся. К концу XVIII в. Семигорье было значительно обезлесено и заросло кустарником. С туристической точки зрения Семигорье под Бонном было важным объектом в Рейнском регионе, оно описывалось в путеводителях с 1784 г. После побед над Наполеоном и Венского конгресса (1815) Рейн начал символизировать свободу немецкого народа, на Драхенфельсе стали проходить экскурсии, военные торжества, патриотические праздники, спортивные и студенческие мероприятия; место начинают посещать иностранные туристы [22].

С 1823 г. начались обширные ремонтные работы в Кёльнском соборе, которые были прерваны (в очередной раз) на время оккупации 


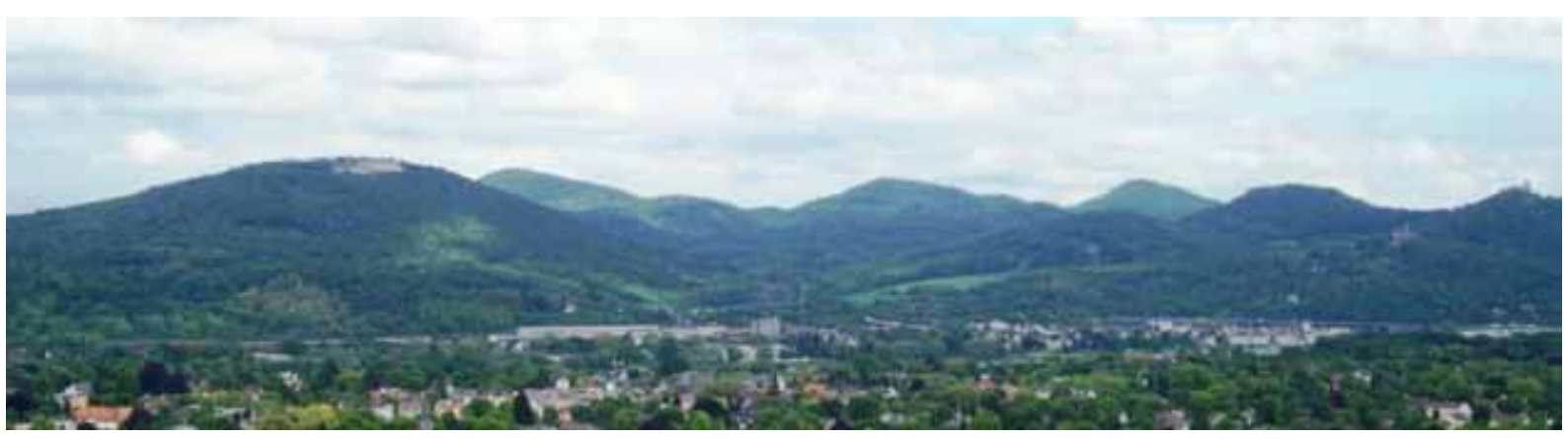

Рис. 1. Семигорье (фотография А.С. Мукало, 2009 г.)

французами. Самой большой проблемой было приобретение стройматериала, который соответствовал бы как техническим, так и художественным потребностям. Альтернатив Драхенфельсу практически не имелось. Бургомистр близлежащего города Кёнигсвинтер Шефер, по совместительству совладелец участка, направил сообщение Королевскому правительству в Кельн и предложил объект для покупки. Правительство сочло 8 тыс. талеров слишком большой ценой. Тогда Шефер в 1827 г. продал гору профсоюзу каменотесов, обеспечив тем самым рабочими местами город и материалом стройку века [22]. Общественность пришла в возмущение, пресса бурлила. Из Берлинских газет король также узнал о творящемся на Рейне «вандализме». Уже через два дня наследный принц направил письмо верховному президенту фон Ингерслебену в Кобленц с просьбой «противодействовать бесчинствам разрушения таких исторических памятников, которые вызваны только корыстолюбием и жаждой наживы» и заверениями, что в финансовом отношении в покупке Драхенфельса готова участвовать семья Гогенцоллерн [23, с. 59]. Отдельно король Фридрих Вильгельм III запросил справку у Кёльнского начальника окружного управления Делиуса, который считал, что даже если Шефер хотел бы оставить руину в неприкосновенности, гарантией сохранности Драхенфельса на длительный срок может быть только покупка участка [23]. Пока шел обмен этой корреспонденцией, разработка горной породы бодро продвигалась.

Во время работ в мае 1828 г. обрушился кусок стены замка, расположенного выше по склону горы. Это дало повод правительству для общего запрета на разработки горной породы. Некоторые исследователи, однако, склонны считать, что тут мерилом законности служила полицейская точка зрения, а не мотивы охраны исторических памятников или природы [24].

Правительству не хотелось платить явно завышенную цену за гору. Таким образом, король решил, наконец, по политическим причинам со ссылкой на беспорядки в Рейнланде обеспечить охрану Драхенфельса посредством экспроприации. Ряд авторов считают именно дату каби- нетского указа «О требованиях общей безопасности» от 23 мая 1829 г. началом охраны утеса Драхенфельс [5, 25]. Как оказалось, спокойствие на гор. Драхенфельс вследствие этого вовсе не наступило, так как рабочие указы проигнорировали. В конце концов во время взрывных работ обрушилась еще часть крепости. По некоторым источникам, произошли кровопролитные столкновения каменотесов, боящихся потерять работу, с жандармами и энтузиастами-«фанатиками охраны природы» $[23,26]$.

Пока представители профсоюза каменщиков писали жалобы во все возможные инстанции, ушлые предприниматели продавали «входные билеты на Драхенфельс» и построили на вершине маленький трактир, а позднее и гостиницу. Разразилась маленькая «война» с правительством, которая подпитывалась негодованием населения по поводу платы за вход. Смерть одного из начальников сообщества каменотесов так сильно ослабила профсоюз, что вопрос о владении горой со временем разрешился. Наследники Драхенфельса и бывшие члены профсоюза продали его в 1836 г. государству за умеренную цену [22]. Таким образом, ряд авторов признают датой начала охраны Драхенфельса 1836 г. [2, 6, 27].

Драхенфельс стал первым комплексным ансамблем, состоящим из архитектурного памятника и его природного окружения, который удалось изъять из хозяйственного использования и оставить - в духе романтизма - как наглядное свидетельство прошлого. Иными словами, в обществе уже созрела готовность к изъятию объектов из хозяйственного пользования, но это еще не было организованным движением.

В 1870-1880-е гг. спрос на базальтовый стройматериал опять поднялся, и соседние с Драхенфельсом горы были подвержены чрезмерной эксплуатации. Перед лицом надвигающегося очевидного разрушения в 1886 г. боннский адвокат Хумбройх обратился с письмом к королевской семье. Оно замечательно тем, что в нем впервые определенно говорится об охране природы и ландшафта: «Если считается обязанностью охранять старинные созданные человеческой рукой произведения, башни, руины замка $<\ldots>$, то красоты 
нашей природы, к чему относится в первую очередь Семигорье, имеют гораздо большее право на почтительное бережное обращение, на охрану от разрушения и опустошения» [28, с. 132]. Тогда же он организовал Союз по спасению Семигорья, работа которого нашла большую поддержку общественности. Решающая помощь, однако, пришла со стороны наследной принцессы Фридерики, которая устроила в Берлине такой скандал по поводу разрушения Семигорья, глубоко любимого на ее родине, что разработки были остановлены [22].

В 1869 г. усилиями старшего начальника над горнорабочими Эрнста Генриха фон Дехена был создан Союз по украшению Семигорья, которому в 1871 г. высочайшим кабинетским указом дали права юридического лица и право отчуждения из горнопромышленного использования в целях охраны природы. Устроенная государственная лотерея помогла собрать более 1 млн золотых марок. На эти деньги Союз по спасению Семигорья в 1899 г. в частном порядке приобрел земельные участки на горах Ольберг и Лорберг, а также лесные массивы по обе стороны Рёндорфской долины, в целом около 800 га $[22,29]$.

\section{Тойфельсмауэр в Гарце}

Указывается несколько версий возникновения названия «Тойфельсмауэр» (в буквальном переводе - «стена дьявола») различной степени «народности», от легенд до сказок братьев Гримм, но, по сути, топоним - отголосок тех времен, когда на этих землях огнем и мечом вводилось христианство. Христианские миссионеры боролись с древними верованиями и культом деревьев. Они давали имена, связанные с ведьмами и чертями, культовым сооружениям, чтобы объявить их вне закона и тем самым отпугнуть от них староверов, вырубали и сжигали старые липы и дубы, под которыми проходили собрания [23, 24].

Останцы представляют собой кварцитовые песчаники (рис. 2). В ходе мощного вздымания Гарца в период с конца мелового по третичный период массив, образовавшийся из морских отложений, перевернувшись на север, поднялся вертикально. В Тойфельсмауэре, проходящем через южную часть общинных полей городов Веддерслебен и Варнштедт, выделяются Кёнигштайн, Миттельштайн и Папенштайн («Королевский камень», «Средний камень» и «Папский камень»), разделенные седловинами, в геологическом отношении - единое целое. Наивысшей точкой Тойфельсмауэра является Миттельштайн (185,2 м, т.е. более 50 м над долиной р. Боде, служащей южной границей нынешней охраняемой области) [30].

В настоящее время природный потенциал Тойфельсмауэра оценивается даже выше, чем в момент постановки его под охрану. С сегодняшней точки зрения это не просто уникальный в геологическом отношении памятник природы, а полиморфная мозаика биотопов, обусловленная микроклиматическими особенностями, и относящиеся к ней редкие виды флоры и фауны. На южной стороне у подножия уступа господствует микроклимат внутренних дюн. Скалы заселяются специфичными для сухих песчаных участков видами. На богатых питательными веществами навеянных свежих лессовых почвах на северных склонах проявляется склонность к быстрому облесению пионерными древесными видами, такими как береза, полевой клен, лесной орех. На обрывистых склонах развились пустоши [31]. Рекреационное значение этого объекта приобрело особый вес после Второй мировой войны. В густо заселенных северных предгорьях Гарца, в первую очередь, в округах Кведлинбург и Тале, Тойфельсмауэр - общепризнанная цель посещения туристов и зона пригородного отдыха.

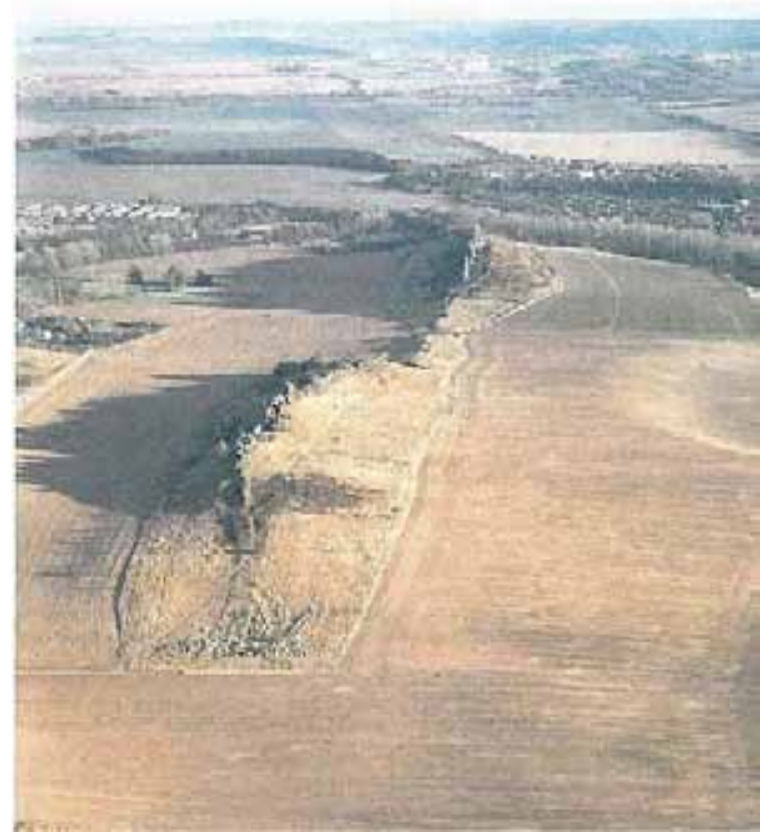

Рис. 2. Тойфельсмауэр [30, с. 5]

История интенсивного использования Тойфельсмауэра достаточно древняя (не считая заселения со времен палеолита). В средние века проходы в Тойфельсмауэре служили важными транспортными путями из Тале в Кведлинбург для торговцев и крестьян. Позднее стали вестись разработки камня. Первые документальные свидетельства (с середины XVII в.) об использовании каменоломен на общинных землях Веддерслебена разными предпринимателями и самой общиной - это церковные счета Веддерслебенской церкви, взимавшей «каменный налог». Сильное разрушение Папенштайна в его западной части говорит о долгом и обширном варварском использовании: в 1714 г. потребовался материал для сооружения новой церкви, в 1723 г. после большого пожара заново отстроили 38 жилых домов с конюшнями [30]. По иронии судьбы в ходе культурно- 
исторического развития расположенных вблизи Тойфельсмауэра деревень происходило все большее разрушение этого памятника природы. C начала XIX в. вблизи останцов стали также добывать песок и глину в небольших карьерах, откуда жители близлежащих деревень брали материал для своих нужд. При этом, согласно летописи Веддерслебенской церкви, происходили несчастные случаи. С 1830-х гг. каменный материал стали использовать для прокладки дорог.

К охране Тойфельсмауэра местные власти подтолкнула реформа в землепользовании, та самая, результатами которой так возмущался основатель движения по охране природных и культурных ценностей страны Эрнст Рудорфф [32]. Целью ее, с одной стороны, было устранение чересполосицы, т.е. объединение сельскохозяйственных земель одного владельца, с другой - разделение совместно используемых территорий, так называемых общинных земель. После того как была проложена новая сеть дорог, а поля заново разделены, начался процесс официального удостоверения согласия землевладельцев с новым распределением земель и компенсации ущерба [3].

Согласно последним данным первое упоминание о постановке этого объекта под охрану относится еще к 1833 г.: в циркулярном предписании жителям Тале, Найнштедта, Веддерслебена и Варнштедта начальник кведлинбургского окружного управления Вейе запретил разработку камней на Тойфельсмауэре. За исполнением этого предписания должен был следить полевой сторож [33].

8 июля 1852 г. в кведлинбургском еженедельнике было опубликовано полицейское постановление: «До нашего сведения дошло, что со скал между Найнштедтом и Веддерслебеном, известных под названием Тойфельсмауэр, часто вытесывают или взрывными работами добывают камни, что, если так и будет продолжаться, приведет к обрушению и разрушению этой скалы. Так как тут имеет место быть разграбление находящегося в нашей местности примечательного объекта, и это угрожает жизни тех, кто работает вблизи скал, то на основе закона полицейского управления от 11.05.1850 г. взымается штраф от 2 до 3 талеров с тех, кто разрабатывает камень в 12 футах от упомянутой скалы» [30, с. 9]. В 1856 и 1860 гг. распоряжения об особых мерах охраны для участков Тойфельсмауера подтвердили оберпрезидент округа Магдебург прусской провинции Саксония и земельный совет (ландрат) [3].

Параграф 20 закона о земельной реформе 1863 г. гарантировал сохранность Тойфельсмауэра с обоснованием того, что этот объект с его редкими формами, особенно Кёнигштайн и Миттельштайн, представляет общественный интерес и потому подлежит охране. Но камни для мостовых пользовались огромным спросом. Община в 1865 г. запретила изъятие оставшихся на полях отдельных камней, чтобы обеспечить собственные потребности, а в 1868 г. ходатайствовала о снятии запрета в целях добычи камня [30]. Начальник районного управления фон Штилов отклонил просьбу: «Если бы в таком вопросе все решали бы только деньги, то, например, также каждая городская община имела бы право продавать или уничтожать старинные памятники архитектуры $<\ldots>$ ценность которых невозможно определить в денежном эквиваленте. Но государственные органы надзора этому препятствуют. Я в любом случае не могу позволить общине Веддерсллебен такое варварство, как намеренное уничтожение Тойфельсмауэра ради создания мостовой» [3, с. 21]. В ответ на дальнейшие жалобы правительство назвало Тойфельсмауэр «предметом народных сказаний и одним из редчайших природных объектов, известной группой скал», чья охрана представляет общественный интерес, что согласовано с § 304 имперского уголовного закона [4, с. 10]. Просьбу общины отклонил и министр по формальным юридическим причинам на основе того, что договор о перераспределении земель может быть оспорен только всеми причастными лицами. Уведомление об отказе содержит также отсылки к фактическим причинам [30]. Тем самым были прекращены споры о добыче камня на Тойфельсмауэре и связанное с этим уничтожение уникальной скалы.

После того как в Пруссии в 1906 г. была создана Государственная комиссия по охране памятников природы под руководством Гюго Конвентца, скалы Тойфельсмауэр были признаны памятником природы, а непосредственно прилегающая к ним территория с 1860 г. считается так называемым резерватом. ООПТ Тойфельсмауэр в ее современных границах возникла только в 1935 г. Затем на эту территорию вплоть до объединения Германии оказывало сильное (и большей частью негативное) влияние развитие сельского хозяйства, так как часть охраняемых земель подверглась распашке, применению биоцидов и т.п. С 2000 г. памятник природы находится в ведении федеральной земли Саксония-Ангальт [3].

\section{Люнебургская пустошь}

В истории Люнебургская пустошь впервые упоминается в 1225 г. после возникновения герцогства Люнебургского [29]. Собственно охраняемая территория представляет собой участок холмистого западного края Люнебургской пустоши и цепь возвышенностей, расположенных в 40 км южнее Гамбурга, в том числе и самая высокая точка в западной части Северо-Германской низменности гора Вильдезер Берг с водоразделом крупнейших рек региона Эльбы, Везера, Аллера. Здесь имеются все характерные для Северо-Германской низменности ландшафты: луга, ручьи, болота и леса. Это древнее пространство расселения человека (первые поселения относятся к неолиту - около 3-4 тыс. лет до н.э.) и один из старейших культурных ландшафтов Германии. 
Она представляет большой интерес с различных точек зрения. К ее образованию привела хозяйственная деятельность человека: в средневековье крестьяне вырубили первоначальные леса и освоили возникшие на этом месте открытые земли. Они занимались пчеловодством и выпасом овец. В результате сформировались почвы, крайне бедные питательными веществами, и специфический ландшафт. С началом индустриализации в начале XIX в. эти земли используются все меньше. $\mathrm{C}$ течением времени обогащение почвы гумусом привело к тому, что типичные для пустоши виды растений вытесняются новыми видами [34].

В 1909 г. в издательство «Kosmos» к Вальтеру Келлеру, надворному советнику в Штутгарте, независимо друг от друга обратились доктор Курт Флорике и молодой доктор из Вены Рихард Зейферт с предложением создать в Германии, «как и во всех культурных странах», природоохранные парки [29]. Идея, опубликованная в журнале, нашла широкий отклик в больших кругах и привела к основанию Союза природоохранных парков в 1909 г. Союз громко объявляет о своей приверженности концепции национальных парков США. Поставлены следующие задачи: охранять естественные и особенно живописные ландшафты с их естественными растительными и животными сообществами от рокового влияния прогрессирующей цивилизации; с одной стороны, разъяснением угрожающих последствий для народа и биологии, с другой - созданием и управлением большими резерватами, служащими образцом. Основной целью стало создание трех природоохранных парков: на равнине, в средне- и высокогорье, т.е. во всех характерных для Германии ландшафтах $[35,36]$.

В то же время пастор Вильгельм Боде из Эгерсдорфа энергично взялся за идею сохранения Люнебургской пустоши. Поначалу ему самому удалось найти несколько спонсоров для покупки участков, которым угрожала застройка, а потом подключился Союз природоохранных парков [29]. На это местные жители сначала отреагировали негативно, но уже в 1911 г. Гамбург предоставил ежегодную дотацию в 10 тыс. марок на подобные мероприятия. Вильгельм II, немецкий кайзер и король Пруссии, поддержал создание парка в пустоши и позволил провести государственную лотерею для Союза природоохранных парков, которая прошла с большим успехом и принесла организации 1,4 млн марок. На эти деньги Союз приобрел большой участок пустоши и тем самым обеспечил охрану центральной зоне природоохранного парка [37].

Дополнение от 8 июля 1920 г. к Прусскому полевому и лесному закону 1880 г. обязало полицейские управления применять специальные инструкции для охраны животных, растений и ООПТ (§34, позднее §30). Полицейским указом министерства от 29 декабря 1921 г. Люнебургская пустошь и указом от 7 июня 1922 г. Семигорье признаны охраняемыми территориями. Тем самым Пруссия поставила под охрану два обширных, широко известных своеобразных ландшафта. Это подтвердила ст. 150 ч. 1 конституции Веймарской республики от 11 августа 1919 г., по которой памятники природы и ландшафт подлежат охране и заботе государства. Имперский закон об охране природы 1935 г. утвердил обе ООПТ. Эти территории, лежащие в поле воздействия урбанизации и индустриализации, сохранились до сегодняшнего дня, но это, скорее, заслуга частных организаций. Положительно сказался тот факт, что покупка этих участков началась в то время, когда земля еще не была объектом спекуляций. Люнебургской пустоши выдан первый европейский диплом как немецкому ландшафту европейского значения. Считается, что при создании этого природного парка зародилась программа природных парков ФРГ, ставшая, в свою очередь, предшественницей Европейской комиссии по охране природы и природным ресурсам при Европейском совете. Таким образом, Люнебургская пустошь, более 50 кв. км площади которой принадлежит Союзу природоохранных парков, и Семигорье, где действовал Союз по спасению Семигорья, являются единственными из крупных ООПТ, большая часть которых принадлежит общественным организациям [29].

\section{Заключение}

На территории современной Германии уже в середине XIX в. были сделаны успешные попытки создания «резерватов культурного ландшафта», где особенно красивые участки природы с ценными историческими объектами сохранялись от дальнейшей хозяйственной деятельности человека и служили для воспитания народного духа. Во-первых, это соответствовало идеалам культурно-исторического течения романтизма, расцвет которого пришелся на первую половину XIX в. Во-вторых, это способствовало сплочению германской нации в ходе формирования единого немецкоговорящего государства. Тем самым, определились важнейшие этапы создания ООПТ: инициатива признания объекта охраняемой территорией, изъятие его из хозяйственной деятельности и гарантия по сохранению. В случае Бамбергской рощи и урочища Тойфельсмауэр инициатива по созданию ООПТ принадлежала государству, в случае горы Драхенфельс инициатива была общественной. Начало сохранения Люнебургской пустоши было положено частным лицом, а потом присоединилась общественная организация. Было выявлено два пути вывода охранных объектов из хозяйственного пользования: изъятие государством, т.е. экспроприация (Бамбергская роща, Тойфельсмауэр) и скупка земель (Люнебургская пустошь), а также их комбинация (Семигорье). В рассмотренных случаях инициатива была поддержана правительством, участки были признаны государственной собственностью и до настоящего 
времени находятся под охраной государства. Таким образом, идея охраны природы в Германии стала реальностью еще до создания теоретических основ природоохранного движения.

Гюго Конвентц, став в 1906 г. руководителем Прусской государственной комиссии по охране памятников природы, направил ее работу на «охрану небольших по площади ООПТ, рассеянных по территории страны, ибо < .. > нетронутые участки ландшафта, растения и животные, не испытавшие на себе влияния человеческой деятельности, и у нас, и в других государствах едва ли сохранились» $[12$, с. 6]. Для большинства же общественных организаций образцом природоохранной деятельности были национальные парки США. При этом мало кто обращает внимание на тот факт, что на практике первые крупные по площади ООПТ в Германии были созданы до того, как стали всемирно известны Йеллоустонский и Йосемитский национальные парки, и в некотором роде предвосхитили их.

\section{Библиографический список}

1. Wegener $U$. Naturschutz in der Kulturlandschaft. Schutz und Pflege von Lebensräumen. Jena; Stuttgart; Lübeck; Ulm: Gustav Fischer Verlag, 1998. 456 S.

2. Zeittafel zur Geschichte des Naturschutzes in Deutschland // Natur und Landschaft. 1990. Heft 3. S. 113-114.

3. George K. Streitigkeiten über Teufelsmauer und ihre Umgebung // 150 Jahre Schutz der Teufelsmauer. Berichte des Landesamtes für Umweltschutz Sachsen-Anhalt / Red. K. George, H.-J. Lerche u. a. Halle: Landesamt für Umweltschutz Sachsen-Anhalt, 2002. S. 20-31.

4. Hilbig W., Wegener U., Behrens H. Die Entwicklung des Naturschutzes und des Naturschutzbeauftragtenwesens auf dem Territorium des Landes Sachsen-Anhalt von den Anfängen bis zur Gegenwart // Lexikon der Naturschutzbeauftragten. B. 2. Sachsen-Anhalt / Bearb. von H. Behrens. Friedland: Steffen Verlag, 2006. S. 1-120.

5. Ant $H$. Daten zur Geschichte des Naturschutzes // Naturschutz, Erholung, Landentwicklung. Jahrbuch für Naturschutz und Landschaftspflege. Verhandlungen Deutscher Beauftragter für Naturschutz und Landschaftspflege. B. 21 / Hrsg. von Dr. W. Erz. Bonn - Bad Godesberg: Arbeitsgemeinschaft Deutscher Beauftragter für Naturschutz und Landschaftspflege e.V., 1972. S. 124-135.

6. Zielonkovski W. Geschichte des Naturschutzes // Ringvorlesung Naturschutz. Laufener Seminarbeiträge. 1989. № 2. S. 5-12.

7. Moewes F. Zur Geschichte der Naturdenkmalpflege // Wege zum Naturschutz / Hrsg. von W. Schoenichen. Breslau: Ferdinand Hirt Verlag, 1926. S. 28-71.

8. Naturpark Kellerwald-Edersee. Entwicklungsplanung. B. I. Bestandanalyse. Bearb. Büro Sollmann. O.O. Hessisches Ministerium für Umwelt, ländlichen Raum und Verbraucherschutz, 2003. $127 \mathrm{~S}$.

9. Friede A., Hoffmann A., Paleit J., Panek N. Forschung in Buchenwald-Nationalparken. Sigmasoziologisch-struckturanalytische Ansätze mit Fokus auf den Nationalpark
Kellerwald-Edersee // Natur und Landschaft. 2005. Heft 12. S. 514-518.

10. Rost B. Beispiellandschaft Rügen // Schriftenreihe des Deutschen Rates für Landespflege. 1997. Heft 67. S. 41-47.

11. Höppner K. 100 Jahre Naturschutzgebiet Plagefenn - ein Beispiel für erfolgreiches Zusammenwirken von Forstwirtschaft und Naturschutz // 100 Jahre Naturschutzgebiet Plagefenn. Ein Beispiel für erfolgreiches Zusammenwirken von Forstwirtschaft und Naturschutz / Red. J. Engel. Eberswalde: Ministerium für Ländliche Entwicklung, Umwelt und Verbraucherschutz des Landes Brandenburg, 2007. S. 11-21.

12. Conwentz H. Die Gefährdung der Naturdenkmäler und Vorschläge zu ihrer Erhaltung. Denkschrift dem Herrn Minister der geistlichen, Unterrichts- und Medizinal- Angelegenheiten überreicht von H. Conwentz. Berlin: Gebrüder Borntraeger Verlag, 1904. 207 S.

13. Klessmann E. Die deutsche Romantik. Köln: DuMont, 1979. $229 \mathrm{~S}$.

14. Berlin I. Die Wurzeln der Romantik. Berlin: Berlin Verlag, 2004. $272 \mathrm{~S}$.

15. Ott K., Potthast T., Gorke M., Nevers P. Über die Anfänge des Naturschutzgedankens in Deutschland und den USA im 19. Jahrhundert // Jahrbuch für Europäische Verwaltungsgeschichte. B. 11: Naturnutzung und Naturschutz in der europäischen Rechts- und Verwaltungsgeschichte / Hrsg. von E.V. Heyen. Baden-Baden: Nomos Verlagsgesellschaft, 1999. S. 1-55.

16. Hölzl R. Naturschutz in Bayern von 1905-1945: der Landesausschuß für Naturpflege und der Bund Naturschutz zwischen privater und staatlicher Initiative. Regensburger Digitale Texte zur Geschichte von Kultur und Umwelt. 2005. № 1. 153 S.

17. Wettengel M. Staat und Naturschutz 1906-1945: Zur Geschichte der Staatlichen Stelle für Naturdenkmalpflege in Preußen und der Reichsstelle für Naturschutz // Historische Zeitschrift. 1993. B. 257. S. 356-399.

18. Klein F. Hermann Löns als Wegbereiter des Naturschutzes // Wie kann man den Himmel kaufen. Naturschutz in Niedersachsen. Hannover: Hejo-Verlag, 1983. S. 11-14.

19. Frohn H.-W. Naturschutz und Staat 1880-1976. Von naturalen Memorialinseln zur Landschaftsökologie // Jetzt ist die Landschaft. Ein Katalog voller Wörter. Beitrage zur Sprache der Ökologie / Red. B. Busch, A. Göbel-Lunemann. Göttingen: Wallstein Verlag, 2007. S. 34-41.

20. Eidloth V. Das Bamberger Hainviertel. Ehemaliges Zentrum des jüdischen Hopfenhandels // Bamberger Geographische Schriften. 1988. Sonderfolge 3. S. 19-152.

21. Sperber G. Bamberger Hain, Deutschlands älteste Waldschutzgebiet - ein Naturerbe von europäischen Bedeutung // Jahrbuch des Vereins zum Schutz der Bergwelt. 2005. № 70. S. 177-188.

22. Roth H.J. Der Drachenfels - von der Polizeiverordnung 1836 bis zum Nationalpark Siebengebierge // Natur im Sinn. Zeitzeugen im Naturschutz. - Beiträge zur Geschichte des Naturschutzes. B. 2 / Hrsg. von Stiftung Naturschutzgeschichte. Essen: Klartext Verlag, 2001. S. 131-142.

23. Sieferle R.P. Fortschrittsfeinde? Opposition gegen Technik und Industrie von der Romantik bis zur Gegenwart. München: C.H. Beck Verlag, 1984. $301 \mathrm{~S}$.

24. Piechocki R. Zum Wandel des Naturschutzverständnisses im Verlauf der letzten einhundert Jahre // Von den Naturdenkmalpflege zum Prozessschutz in den Nationalparken. Wege zu 
einer ganzheitlichen Naturschutzstrategie / Bearb. von Behrens H., Sacher P., Wegener U. Berlin: Verlag für Wissenschaft und Forschung, 2002. S. 5-47.

25. Knaut A. Zurück zur Natur! Die Wurzeln der Ökobewegung, Suppl. 1 zum Jahrbuch für Naturschutz und Landschaftspflege. Greven: Kilga-Verlag, 1993. 480 S.

26. Schoenichen $W$. Naturschutz - Heimatschutz. Große Naturforscher. B. 16. Stuttgart: Wissenschaftliche Verlaggesellschaft M.B.H., 1954. 311 S.

27. Blab J. Schutzgebiete in Deutschland - Entwicklung mit historischer Perspektive // Natur und Landschaft. 2006. Heft 1. S. 8-11.

28. Barthelmeß A. Landschaft. Lebensraum des Menschen. Probleme von Landschaftsschutz und Landschaftspflege geschichtlich dargestellt und dokumentiert. Freiburg; München: Verlag Karl Alber, 1988. 384 S.

29. Offner H. Die Lüneburger Heide // Jahrbuch Preussischer Kulturbesitz. 1971. Sonderdruck. № IX. S. 3-20.

30. Lerche H.-J. Die Teufelsmauer bei Weddersleben und Warnstedt // 150 Jahre Schutz der Teufelsmauer. Berichte des Landesamtes für Umweltschutz Sachsen-Anhalt / Red. K. George, H.-J. Lerche u. a. Halle: Landesamt für Umweltschutz Sachsen-Anhalt, 2002. S. 6-11.
31. Stempel A., Ohlendorf B. Zur Bedeutung, Pflege und Entwicklung des NSG «Teufelsmauer»// Ibid. S. 16-19.

32. Rudorff $E$. Über das Verhältnis des modernen Lebens zur Natur // Natur und Landschaft. 1990. Heft 3. S. 119-125.

33. Funkel C., George K. Die «Teufelsmauer»-eines der frühesten Schutzobjekte in Deutschland - älter als gedacht // Naturschutz im Land Sachsen-Anhalt. 2002. Heft 2. S. 50-52.

34. Kaiser T., Lütkepohl M., Prüter J. Das Naturschutzgebiet Lüneburger Heide als Beispielgebiet des Werkstattgesprächs «Naturschutzleitbilder»// Schriftenreihe des Deutschen Rates für Landespflege. 1997. Heft 67. S. 71-73.

35. Floericke K. Entwicklung, Stand und Aussichten der Naturschutzparkbewegung // Naturschutzparke in Deutschland und Österreich. Ein Mahnwort an das deutsche und österreichische Volk. Hrsg. vom Verein Naturschutzpark e. V. Sitz Stuttgart. Stuttgart: Frank'sche Verlagshandlung, o. J. S. 7-18. 36. Guenther K. Der Naturschutz. Freiburg i. B.: Verlag Friedrich Ernst Fehlenfeld, 1910. 278 S.

37. Der Verein Naturschutzpark e.V. besteht 80 Jahre. Die Geschichte des Vereins in Stichworten von 1909 bis 1988 // Naturschutz- und Naturparke. Mitteilungen des Vereins Naturschutzpark e.V. und des Verbandes Deutscher Naturparke e.V. 3. Vierteljahr 1989. Heft 134. S. 41-47.

\section{КРУПНОМАСШТАБНОЕ ЛАНДШАФТНОЕ КАРТОГРАФИРОВАНИЕ (на ПрИмере полупустынного Саратовского Приузенья)}

\section{Н.В. Пичугина, А.В. Фёдоров ${ }^{1}$}

Саратовский государственный университет, кафедра физической географии и ландшафтной экологии,

${ }^{1}$ кафедра геоморфологии и геоэкологии,

E-mail: geogr@sgu.ru

Статья посвящена вопросам картографирования локальных геосистем полупустынного Саратовского Приузенья, а также возможностям использования картографических произведений для определения ландшафтной структуры и ее изменений вследствие антропогенной нагрузки на территорию. В работе использованы материалы полевых исследований разных лет, топографические и тематические карты, космические снимки, элементы геоинформационных технологий.

Ключевые слова: картографирование, ландшафты, полупустыня, Саратовская область, Заволжье.

\section{Large-Scale Landscape Mapping (Semi-Desert Saratov Priuzenye as an Example)}

\section{N.V. Pichugina, A.V. Fedorov}

The article is devoted to mapping questions of local semi-desert Saratov Priuzenye geosystems and facilities of cartographical works using for landscape structure identification and it's variation as a result of anthropogenic load on the territory. Different ages field research, topographical and thematical maps, space images, geoinformation technology' elements are used in the work.

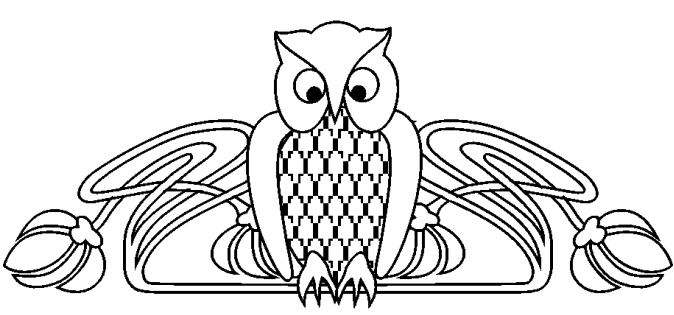

Key words: mapping, landscapes, semi-desert, Saratov Region, Zavolzhye.

Основным назначением ландшафтного картографирования выступает разработка методики составления, оформления и анализа картографических произведений, отображающих природные и природно-антропогенные геосистемы локальной, региональной и планетарной размерностей.

Целью данной статьи является рассмотрение возможностей использования крупномасштабного картографирования геосистем локального уровня для изучения ландшафтной структуры, а также ее трансформации в процессе сельскохозяйственного использования территории.

В качестве объекта исследования была выбрана Приузенская равнина с трехчленными пустынно-степными комплексами (ПСК). Административно она охватывает юго-западную часть Новоузенского района (к югу от широты г. Новоузенска) и Александрово-Гайский район Саратовской области.

Актуальность выбранной темы определяется необходимостью оптимизации структуры землепользования территории.

Исходные материалы и источники. При написании статьи были использованы материа- 